\title{
The Persistence of Inequity in Brazilian Higher Education: Background Data and Student Performance
}

\author{
Julio Bertolin and Tristan McCowan
}

\section{INTRODUCTION}

While being the world's eighth largest economy, Brazil is one of the most unequal countries in the world. In 2017, for example, Brazil's GDP was approximately USD 3.3 trillion, larger than that of countries such as Russia, Canada, Australia and Spain. In terms of income distribution, however, even after some improvement in recent decades, Brazil is still the tenth worst country, as measured by the Gini coefficient (UNDP, 2016). In 2017, there were 55 million Brazilians living below the poverty line, subsisting on up to USD 5.50 per day, which accounts for a quarter of the country's population (IBGE, 2018). In 2015, the share of national income of the richest 1 per cent of Brazilians was 28.3 per cent, giving it the

\footnotetext{
J. Bertolin $(\bowtie)$

Universidade do Passo Fundo, Passo Fundo, Brazil

e-mail: julio@upf.br

T. McCowan

University College, London, UK

(C) The Author(s) 2022

O. Tavares et al. (eds.), Equity Policies in Global Higher Education, Issues in Higher Education, https://doi.org/10.1007/978-3-030-69691-7_4
} 
world's second highest level of income concentration. Only Qatar, a dynastic Arab emirate of 2.6 million inhabitants, exceeds Brazil in that particular indicator (WID, 2015).

Social policy analyses indicate that: (i) as a share of income, Brazil is the country that least transfers funds to those who earn the least and that most transfers funds to those who earn the most; and (ii) in absolute terms, transfers to the richest 20 per cent represent almost half of the total, with a significant share of those transfers taking the form of pensions. That is why, according to a 2019 World Economic Forum Report, while a Danish family in the lowest-income group needs only two generations to achieve an average income level, in Brazil, families in the equivalent group would require nine generations. Brazilian inequality has historic causes, such as the fact that it was the last country in the Americas to abolish slavery, in 1888. In education, in addition to the fact that its first university was only established 400 years after the first university in Spanish America, during the 1990 World Conference on Education for All, in Jomtien, Thailand, Brazil was exposed as having one of the lowest literacy rates among the most populous countries in the world.

In this context of extreme social inequality, obtaining an undergraduate degree has become a key factor to enable social mobility. In Brazil, a higher education degree means that one has significant social and economic advantages. Various studies provide evidence that a university education is a strong conditioning factor for improved compensation and higher professional status (de Souza et al., 2010; IBGE, 2018). On average, in OECD countries, individuals with undergraduate degrees earn 1.6 times more than those with only a secondary education; in Brazil, they earn approximately three times more (OECD, 2018). In 2017, a worker with only primary education earned USD 457 per month and one with only secondary education earned USD 535 per month, while a worker with a higher education degree earned USD 1518 per month (Semesp, 2019).

Completing a higher education course also improves job security. The recent Brazilian economic crisis has led the unemployment rate to jump from 6.9 per cent in 2014 to 12.5 per cent in 2017, equivalent to $6.2 \mathrm{mil}$ lion more people in search of an occupation. In 2017, the unemployment rate for people with only primary education was 14.7 per cent for white Brazilians and 19.7 per cent for black Brazilians (which here includes 'negros' [black people] and 'pardos' [mixed-race people]). For those with a higher education degree, the rate was only 6.3 per cent for Brazilian whites and 7.4 per cent for Brazilian blacks (IBGE, 2018). 
Therefore, expanding Brazilian higher education is an important step to face the challenge of extreme social inequality. To that end, in the attempt to widen the participation from members of disfavoured groups and achieve higher equality of opportunity in the country, Brazilian governments have lately made a series of efforts to expand access to higher education. In addition to passing regulations to certify for-profit institutions in the mid-1990s, several programmes were established from 2000 onward to facilitate access to federal (e.g., Lei de Cotas [affirmative action legislation]) and private institutions (e.g., refundable [Fies] and nonrefundable [Prouni] credits). In 2014, when the net enrolment ratio (NER) was approximately 18 per cent, the Brazilian National Education Plan established a target NER of 33 per cent by 2024 . Though the implementation of some of these expansion policies is relatively recent, their quantitative impact is already evident. As shown in Fig. 4.1, in the last three decades, absolute enrolment numbers grew from approximately 1.5 million students to over 8 million (INEP, 2017).

In terms of the NER, achievement grew from 7.4 per cent in 2000 (Corbucci, 2014) to 20 per cent in 2017 (Todos pela Educação, 2019). During the same period, the number of students completing their

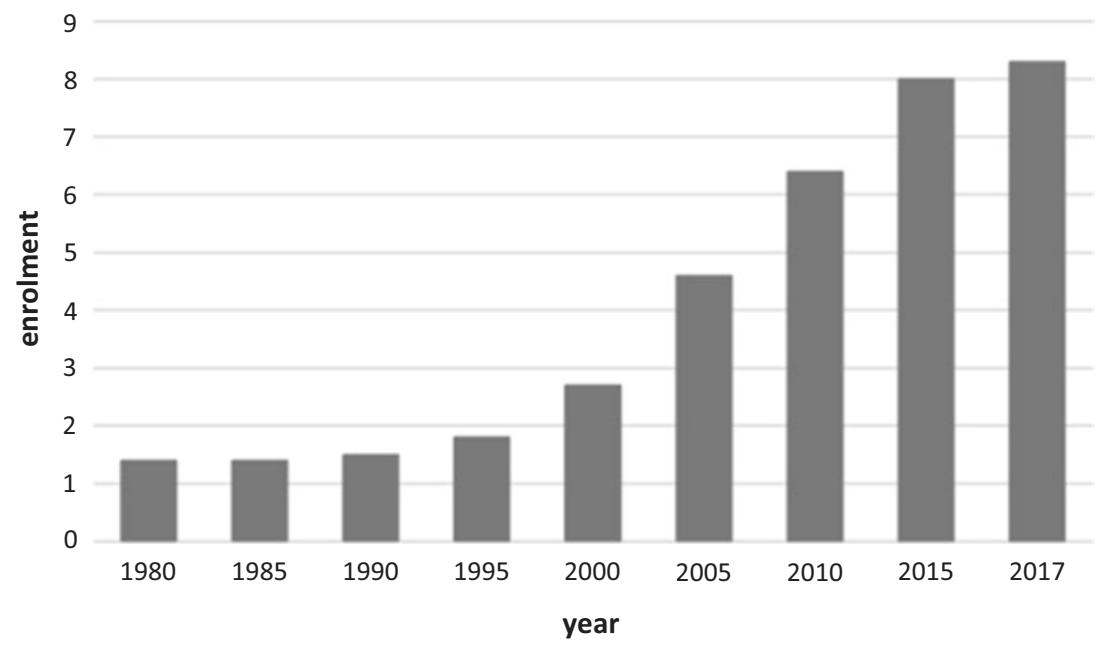

Fig. 4.1 Growth of student enrolment (in millions) in Brazilian higher education, 1980-2017 
undergraduate degree tripled, reaching almost 1.2 million per year (INEP, 2017). This expansion led to higher ratios of young-to-older Brazilians with undergraduate degrees: 20 per cent of those between 20 and 34, compared to 14 per cent for those aged 55 to 64 (IBGE, 2018). Though many hold jobs that do not require high qualification levels, currently over 18 per cent of the Brazilian workforce holds an undergraduate degree, an important increase over the less than 14 per cent from 2012 (IPEA, 2017). In short, various indicators point to a significant expansion in Brazilian higher education.

However, simple increases in achievement and access indicators do not ensure the system is becoming fairer and provide more equal opportunities for young people from various cultural and socioeconomic backgrounds. In addition to access rates, one should also take into account the nature of the national higher education system. The expansion process, especially in such an extremely unequal country, should be assessed based on democratisation and equity trends. Therefore, one relevant question to be asked is whether the expansion of Brazilian higher education is providing opportunities for all social groups or simply reproducing inequalities. This is an important subject, since, despite the overall relevance of undergraduate degrees as a conditioning factor for social mobility in the country, the Brazilian system contains significant differences in terms of positional goods and academic values between institutions, courses, and modes of education. As argued by Marginson (2004), social groups from deprived backgrounds are not in a good position to compete for positional goods and academic status, which tend to be monopolised by social groups from privileged backgrounds. A possible consequence of this competition is the persistent inequality at the level of higher education.

According to McCowan (2016), there are three dimensions of equity of access to higher education. First, availability, meaning the existence of higher education institutions with adequate infrastructure and personnel, indicating there are enough available places for students who want to pursue a higher education degree. The second element is accessibility, referring to students' ability to actually enrol and occupy those available places. A series of obstacles might prevent them from enrolling, such as tuition fees and highly selective admissions criteria, as well as geographic distance and aspirations, among other factors. Systems have high accessibility levels when they include measures to overcome these obstacles and ensure substantive equality of opportunity in the admissions process in addition to formal equality. Finally, systems are considered horizontal when 
institutional differentiation is based on orientation, area or mission, not quality or conferment of positional goods in the labour market.

Considering that key question and the theoretical framework discussed, we next analyse the actual expansion of Brazilian higher education in previous years in terms of horizontality. We break down changes in profiles of enrolees, the socioeconomic and cultural characteristics of graduates by type of institution, by courses/careers, and compare to graduates' performance by socioeconomic level in the various modes of the Brazilian higher education system.

\section{Advances in Diversity of Enrolee Profiles: Only THE BEGINNING}

The expansion of Brazilian higher education in recent years is changing student profiles, unlike the expansion in the 1990s, when few students from lower socioeconomic backgrounds gained access. In 2002, no student belonged to the poorest 20 per cent of the population and only 4 per cent belonged to the poorest 40 per cent. In 2015 , approximately 15 per cent of higher education students belonged to the poorest 40 per cent of Brazilians (World Bank, 2017).

This change is likely the outcome of public policies focused on the democratisation of access implemented in the first years of the twenty-first century. At federal institutions, this initiative took primarily the form of affirmative action. Quotas Law (Act 12.711/2012, the Affirmative Action Act) sought to increase access to Federal Institutes and Universities, establishing a 50 per cent quota for public school students in all courses, in addition to sub-quotas for lower-income students who could prove family income of up to 1.5 minimum salaries per capita as well as for black, mixed-race and indigenous students.

At private institutions, whether for-profit or non-profit, major public policies focused on the democratisation of access include Programa Universidade Para Todos (University for All Programme-Prouni) and Fundo de Financiamentoao Estudante do Ensino Superior (Higher Education Student Fund-Fies). Prouni came about with the enactment of Act 11.096/2005, regulating the provision of full and partial (50 per cent) scholarships for higher education courses at private colleges and universities. Prouni is targeted at students with family incomes of zero to three minimum salaries per capita who attended public secondary schools 
or received scholarships to attend private secondary schools. When distributing scholarships, institutions are required to set aside a quota for students with disabilities and those self-declaring as black and indigenous at the same rate as those races and ethnicities are found in their state, according to the latest census from IBGE. To be part of the programme, institutions are required to provide scholarships for new cohorts on all of their courses. In exchange, they are exempt from a given set of taxes and fees. Prouni is a form of non-refundable public financing.

FIES, in turn, established under that name in 1999, is a public loan scheme. Regulated by Act 10.260/2001, it consists of financial support through the provision of funds to students enrolled in higher education courses at private institutions that obtained positive evaluations upon finishing their secondary education. As a form of refundable financing, after graduating, students benefiting from the programme are required to return the funds at below-market interest rate. Access criteria and interest rates have been altered over the years, with a recent change creating the so-called New FIES in 2018, dividing the programme into modes.

A comparison with the immediately preceding period allows us to better understand the scope of these programmes. The expansion process that took place before the establishment of programmes such as Prouni, Quotas Law and Fies was clearly restricted in terms of promoting diversity in student profiles. A study by Schwartzman (2004) shows that, despite the number of enrolees more than doubling between 1999 and 2002, lower-income students scarcely gained at all: the percentage of students from the top 10 per cent in income fell slightly, from 43.9 to 41.4 per cent, the share of students from families in the bottom half of the income distribution also fell, from a low rate of 8.6 per cent to 7.5 per cent. Therefore, that initial expansion period almost exclusively benefited the middle and upper-middle classes.

On the other hand, from 2005 to 2018 , almost 2.5 million students enrolled in undergraduate courses at private institutions using Prouni non-refundable financing, which is restricted according to social criteria (Ministério da Educação, 2019). A recent Instituto Brasileiro de Geografia, Estatística (IBGE) study (2019) relates the establishment of an affirmative action system to the fact that, for the first time ever, the number of black students in public higher education institutions has surpassed the number of white students. In 2018, Brazil had over 1.14 million students selfdeclaring as black or mixed-race ('pretos' and 'pardos'), while whites were 1.05 million in federal, state and/or municipal institutions. The numbers 
represent 50.3 and 48.2 per cent, respectively, of the over 2.19 Brazilians enrolled in those institutions.

The more recent process of expanding access, however, still falls short of meeting the National Education Plan target of 33 per cent and has been unable to fully resolve the high levels of inequality present in the beginning of the century. Enrolments by race show that, though the gap is diminishing, there are still stark differences between groups. According to IBGE, in $2015,45.22$ per cent of Brazilians self-declared as white, 45.06 per cent as 'pardo' (mixed-race), 8.86 per cent as 'preto' (black), 0.47 per cent as Asian, and 0.38 per cent as indigenous. In terms of enrolment rates, while 30.7 per cent of young whites were enrolled in institutions of higher education in 2018 (almost reaching the 33 per cent target), black and mixed-race student were significantly below that level, with only 15.1 and 16.3 per cent enrolled, respectively (Todos pela Educação, 2019). Among secondary school graduates, only 33 per cent of black and mixedrace students enrolled in higher education institutions, compared with 52 per cent of white students (IBGE, 2018).

Most Brazilian secondary school students go to public schools (88 per cent) (IBGE, 2018), but have significantly worse outcomes than their private sector peers. In 2017 , only 36 per cent of public school graduates were able to enrol in institutions of higher education. For private school students, that number was 79 per cent. In effect, that means students from higher-income families have higher access rates in Brazil.

In terms of gender, women are a substantially larger share of those enrolled in higher education institutions. Women represent 55.4 per cent of students enrolled in traditional classroom-based courses and 60.5 per cent of graduates (INEP, 2019). However, as in most countries, there are significant differences between men and women in courses chosen, and this is a contributing factor to women's lower returns in the labour market (ILO, 2018). While female students are 75 per cent of students in education and other teacher-training courses, their share falls to 37.4 per cent for engineering, production and construction, and to 13.8 per cent for information and communications technology and computer science (INEP, 2019).

Therefore, though access for students from lower socioeconomic backgrounds has increased significantly over the last 15 years, further advancements are clearly needed: in 2014, only 5 per cent of children of Brazilians with little education (up to 5 th grade) managed to obtain an undergraduate degree. Among children from parents with higher education degrees, 
70 per cent secured a diploma (IBGE, 2017). Therefore, it could be said that changes in profile and social diversity among Brazilian higher education students have led to greater equity but are only just starting.

\section{Changes in Social Profiles of Graduates: Elitist LeFTOVERS}

As paradoxical as it may seem, access to undergraduate courses for lower socioeconomic groups may, in some cases, pose new challenges to those students. Some young men and women from different social backgrounds entering the world of higher education fail in academia and drop out before finishing their degrees. For students from vulnerable and/or exclusionary backgrounds in Brazil participating in programmes such as Prouni and Quotas Law, other factors increase the odds of 'school failure' or dropping out.

One factor at play is the difficulty in settling into a strange new world (academia), distant from their daily lives, characterised by an ethos, a system of values and habits in a context with which they are not familiar (Bourdieu, 1966; Figueiredo, 2018). Another factor is the prejudice and discrimination scholarship students and affirmative action students suffer due to the very nature of their admission (considered unfair by many) and to their lower cultural and socioeconomic status (Lemos, 2017; Neves et al., 2016). Therefore, in the Brazilian case, a proper analysis of the system's equity requires that the scope of studies go beyond access and include aspects related to retention and completion.

To that end, with the goal of assessing that trend in Brazilian higher education, Enade (Exame Nacional de Desempenho de EstudantesNational Student Performance Examination), an instrument deployed throughout the country, allows us to study the socioeconomic and cultural profile of students completing undergraduate courses. Since 2004, with the implementation of Sinaes (Sistema Nacional de Avaliação da Educação Superior-National Higher Education Assessment System), students completing a set of courses in certain careers and knowledge areas take the Enade exam every three years. Though the examination alternates between courses annually, the number of students taking Enade regularly is significant, providing a public database that serves as an important sample of Brazilian higher education graduates. In 2014, for instance, almost 500 thousand students finishing their degrees took the 
examination, at a time when the total number of enrolees in the Brazilian system was a little over 7 million (Bertolin et al., 2019).

Over the last three Enade cycles, for the various sets of courses and careers (Group 1, primarily applied social sciences, held in the years 2009/2012/2015; Group 2, primarily health and agricultural sciences, held in the years 2010/2013/2016; and Group 3, primarily engineering and teacher-training, held in the years 2011/2014/2017), the data show that the population of graduates is undergoing a process of increasing participation rates for students admitted through affirmative action policies (Quotas Law) or public funding (e.g., Prouni and Fies), which democratise access.

Graduates supported by Prouni and Fies increased from 10 to 26 per cent between 2009 and 2015; from 11 to 37 per cent between 2010 and 2016; and from 8 to 22 per cent between 2011 and 2017. Likewise, the number of students admitted through affirmative action programmes, such as Quotas Law, over the last three cycles increased as a share of graduates, increasing from 10 to 18 per cent between 2009 and 2015 , from 12 to 21 per cent between 2010 and 2016 , and from 16 to 22 per cent between 2011 and 2017 (INEP, 2019).

The growth in the number of students from lower socioeconomic levels among graduates happened in both public and private institutions, but it should be emphasised that they did not grow at the same rate. In Brazil, that statement indicates a serious issue. Analysing the profiles of students graduating from undergraduate programmes in the two sectors with the most students (federal institutions and private for-profit institutions) allow us to identify key trends in the process of expansion with stratification.

From 2009 to 2017 , despite the ratio of students from lower socioeconomic backgrounds finishing their degrees having increased in both sectors, that group was more prominent in for-profit institutions (Fig. 4.2).

In federal institutions, the percentage of graduates whose mothers had only a 5 th grade education or lower (an indicator of poor background and limited family schooling) increased from 16 per cent in the first cycle of Enade to 19 per cent in the third cycle, but in for-profit private institutions that increase was from 30 to 35 per cent. As for the low family income indicator (up to three minimum salaries), the percentage of graduates increased from 31 to 39 per cent during the period, but the increase was much larger in the for-profit private sector, jumping from 30 to 49 per cent (INEP, 2019). In other words, despite the badly needed 


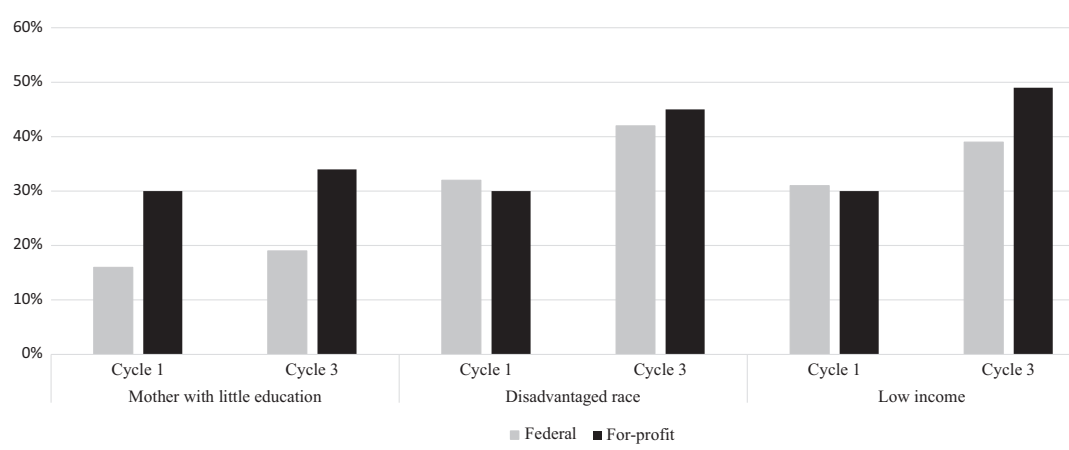

Fig. 4.2 Increase in students of lower socioeconomic level among graduates taking Enade (average of cycles 2009/2010/2011 and 2015/2016/2017)

improvements in the public sector, the ratio of graduates from disfavoured groups increased less than in the for-profit sector.

In Brazil, differences between private and public institutions of higher education are highly significant. Most of the country's scientific research is concentrated in its public institutions, while private institutions, with the exception of non-profits, rarely produce academic research. In a recent study from the World Bank (2017), graduates from for-profit institutions were shown to have, on average, the worst results at Enade. For this and many other reasons, public institutions are recognised both in the media and by society at large as sources of quality and academic values. Consequently, young students and their families generally aspire to a place at a federal university. However, many students do not have the economic resources and family education background that would allow them to reach an academic performance level required to enter a federal university due to the highly competitive nature of their admissions process. A recent study shows that, at zero-tuition federal institutions, only 20 per cent of students come from the bottom two quintiles of the population in terms of wealth, while 65 per cent come from the top two quintiles (World Bank, 2017). Thus, the gaps in participation rates between groups with different socioeconomic levels at federal institutions highlight the inequality of opportunity within the system.

Just as there are qualitative differences between categories of institutions (federal and private for-profit) in the Brazilian higher education system, there are also significant differences in social status and positional 
goods provided to graduates by the various courses and corresponding careers. That difference can be measured in the selection processes. For instance, medicine courses whose graduates have the highest average salaries in Brazil usually have the most competitive admissions process both in federal and private institutions. In the federal system, up to 100 students apply for each slot. In the for-profits, it is not unheard of for tuition fees to exceed USD 2000 per month (a high amount even for the middle class in Brazil). In comparison, courses for Portuguese language teachers, which train basic education workers, sometimes do not fill all available places, despite being free at public institutions and having tuition of less than USD 100 per month at private institutions. In recent years, Enade has seen significant differences in participation by students from disadvantaged groups in different courses (see Table 4.1).

Between 2009 and 2017, despite the increasing number of low-income students in all courses, the most significant increase came from courses with lower social status, those that do not provide positional goods and generally confer lower potential future income (INEP, 2019). In the highly sought-after medicine courses, the percentage of graduates whose mother had only a 5 th grade education or below increased only from 3 to 5 per cent in federal institutions and stayed at 3 per cent in private institutions, while in low-demand social work courses the number increased from 21 to 28 per cent in federal institutions and from 27 to 51 per cent in for-profit institutions. If, on one hand, in high-status civil engineering

Table 4.1 Ratios of higher education graduates in the last Enade examination (2015-2016-2017) from non-white backgrounds, low-income families, public secondary schools and mothers with low educational levels, by course

\begin{tabular}{lcccc}
\hline Course & $\begin{array}{c}\text { Disadvantaged } \\
\text { racialgroup }\end{array}$ & $\begin{array}{c}\text { Low- } \\
\text { income }\end{array}$ & $\begin{array}{c}\text { Public secondary } \\
\text { education }\end{array}$ & $\begin{array}{c}\text { Mother with low } \\
\text { educational level }\end{array}$ \\
\hline Bus & $39 \%$ & $38 \%$ & $70 \%$ & $32 \%$ \\
management & $37 \%$ & $29 \%$ & $48 \%$ & $21 \%$ \\
Law & $26 \%$ & $13 \%$ & $15 \%$ & $4 \%$ \\
Medicine & $63 \%$ & $71 \%$ & $80 \%$ & $51 \%$ \\
Social work & $35 \%$ & $36 \%$ & $53 \%$ & $17 \%$ \\
Civil & & & & $43 \%$ \\
engineering & $56 \%$ & $67 \%$ & $78 \%$ & \\
Portuguese & & & & \\
\hline
\end{tabular}

Source: McCowan and Bertolin (2020) 
courses the percentage of non-white students increased from 27 to 33 per cent at federal institutions and from 26 to 41 per cent at for-profit institutions, for courses for Portuguese language teachers, the same indicators rose from 52 to 60 per cent at federal universities and from 43 to 50 per cent at for-profit institutions.

In general, an analysis of Enade results from 2009-2017 shows that undergraduate courses with higher social status and that generate higher potential gains for graduates, such as medicine, have provided fewer access opportunities for non-white students, students from low-income families, graduates from public secondary schools, and students whose mothers had little education. This is consistent with Lucas' (2001) theory of Effectively Maintained Inequality (EMI) that relates the socioeconomic status and educational inequalities through the lens of rational choice. This theory suggests that groups with a higher socioeconomic background, in the context of expanding access, seek qualitative differences to guarantee diplomas that provide greater prestige and represent a positional good. In other words, what really makes the difference is no longer accessing higher education, but attending courses at the best research institutions that generate more status and income.

Thus, McCowan and Bertolin (2020) argue that students belonging to disadvantaged social groups are more likely to finish their degrees in lowerquality institutions and in courses that are less socially and economically valued, preserving remnants from the elitist system of the previous century.

\section{Performance of Graduates from Different Modes of Education: Quality Inequity}

The expansion in Brazilian higher education took place at both public and private institutions, and was more significant in the latter, especially at forprofit institutions. The trend is evident in the participation rates of private institutions in terms of enrolment, where it grew from 58 per cent in 1995 to 75 per cent in 2018 (INEP, 2019). As we have seen, the qualitative differences between public and private institutions of higher education run in the opposite direction, i.e., federal institutions are at an advantage in that regard. In recent years, the expansion in private institutions has been supported by the distance education (DE) system.

In 2005, distance education courses accounted for less than 2 per cent of total enrolments at private institutions; a little over 10 years later, that 
mode of education accounted for 30 per cent of all enrolments. Currently, over 90 per cent of all DE students in the Brazilian system study in private institutions. Between 2015 and 2018, admissions for distance education students more than doubled, going from under 700 thousand to approximately 1.4 million, while classroom-based courses took a step back, from 2.2 to 2.1 million. In 2018 , for the first time, the number of openings offered in this mode of education was higher than the number for classroom-based courses, at 7.2 versus 6.4 million (INEP, 2019).

In the case of expanded access to DE in Brazil, a further complicating factor is that DE students usually have lower socioeconomic profiles than students attending traditional classroom-based courses. On average, they are more often graduates of public secondary schools ( 80 per cent of DE students come from public schools, versus 60 per cent in classroom-based courses), are enrolled in courses with lower perceived social status (e.g., teacher training), and pay lower tuition fees (average monthly fees for a DE bachelor's degree are almost one third of those for a traditional classroom-based course) (Semesp, 2019). Combined, these factors impacting the expansion of this mode of education, targeted at a specific student profile, may be giving members of lower socioeconomic groups access to inferior education. Therefore, assessing DE quality has become critical in the context of analysing the system in terms of equity.

Thus, it should be stressed that, since the mid-twentieth century, studies have shown that school or undergraduate course attributes and characteristics are not the only factors to determine student performance in examinations. From that period on, studies such as the Coleman Study and The Plowden Report have shown that, unlike what some authors believe, there is another very important variable beyond school quality: background, i.e., students' family, social, economic and cultural 'stores' (Coleman et al., 1981; Department of Education and Science, \& Plowden, 1967). When students of lower socioeconomic levels are able to overcome these disadvantages and outperform their more privileged counterparts, in these cases, the quality of the educational institution is likely to be the most relevant factor. That is precisely what performance comparisons between graduate profiles and modes of education in Brazilian undergraduate courses have revealed.

Disaggregating mode of education and background, the average student scores at Enade show that students from traditional classroom-based courses have significantly higher performance levels than those graduates from the three biggest DE courses in Brazil. In addition to this 
performance gap, however, data analysis also shows that, in most cases, students with lower socioeconomic levels enrolled in classroom-based courses achieve higher scores at the 'specific knowledge' part of the examination than students from higher socioeconomic levels from DE courses (see Table 4.2).

In Business Management and Social Work courses, for all socioeconomic aspects considered (race, family income, mother's schooling, attending private or public secondary schools, work situation), the superior influence of the mode of education was evident. In other words, in these cases, students from lower socioeconomic backgrounds in traditional classroom-based courses outperformed those with higher backgrounds in DE courses.

Table 4.2 Comparison of average 'specific knowledge' scores of graduates from traditional classroom-based courses and DE courses by subgroups from different backgrounds-business management (Enade 2015), social work (Enade 2016) and education (Enade 2017) courses

\begin{tabular}{lccc}
\hline \multirow{2}{*}{ Background subgroup/Mode of education } & \multicolumn{3}{c}{ Courses } \\
\cline { 2 - 4 } & Bus mgt & Social work & Education \\
\hline Blacks and mixed-race/Trad & 36.8 & 48.3 & 41.2 \\
Whites/DE & 33.7 & 39.6 & 39.7 \\
3 MS or less/Trad & 35.9 & 47.1 & 41.3 \\
4.5 MS or more/DE & 35.6 & 42.4 & 46.3 \\
Mother with low educational level/Trad & 35.1 & 44.8 & 38.9 \\
Mother with higher education degree/DE & 34.7 & 38.2 & 41.4 \\
Public school/Trad & 37.3 & 47.9 & 42.3 \\
Private school/DE & 36.8 & 40.6 & 46.0 \\
Studies and work/Trad & 38.0 & 48.3 & 43.0 \\
Only studies/DE & 32.0 & 37.0 & 37.0 \\
\hline
\end{tabular}

Source: The authors, based on microdata from INEP (2019)

Note: Trad-Traditional classroom-based course. DE-Distance education mode MS: Minimum salary

Bus mgt: Business management

${ }^{1}$ The Enade test is taken every year by students completing undergraduate courses in specific disciplinary areas. It evaluates the performance of students via a two-part test: the 'specific knowledge' part with content on the degree course studied; and the 'general education' part which covers general knowledge and topics outside of the particular professional or academic area of the student. 
Therefore, by applying the theories that emphasise the importance of student background to their performance in examinations, as well as comparisons between classroom-based and DE modes of education at Enade, which point to higher performance for students attending traditional classroom-based courses, regardless of socioeconomic level, it would be plausible to argue that, in Brazil, the traditional mode of education provides better learning conditions.

As DE aggregates student profiles who usually come from lower socioeconomic levels, the reproduction of inequalities through the expansion of private distance education is clear. Although acknowledging that DE may play an important role in widening access for distant locations in a country of continental size such as Brazil, the evidence shows that this particular mode of education has major limitations. The people who most need a teacher present are paying to study in distance education and enrolling in courses of dubious quality, while people from privileged backgrounds have access to classroom-based courses at the finest institutions, often free of charge. It could therefore be said equity in quality is absent from the system.

\section{Conclusion}

In the last three decades Brazil's enrolments grew from approximately 1.5 million to more than 8 million students (INEP, 2017). Despite this step forward in access, indicators are unimpressive by international standards. In 2017, the proportion of higher education graduates aged 25 to 34 in Brazil was 18 per cent, a number close to China's (19 per cent) and above India's (14 per cent), but still below Chile (30 per cent) and less than half the OECD average of 43 per cent (OECD, 2018).

In addition to progress in general achievement rates, the last 15 years also witnessed wider democratisation of access. The share of students from lower socioeconomic levels among enrolees and graduates has increased significantly even in the high prestige federal sector. This is an important step in decreasing inequality, since an undergraduate degree is almost always a source of better professional, social and income opportunities in Brazil.

When analysing the higher admission and graduation rates of students from lower socioeconomic levels in terms of the various courses/careers and modes of education present in the Brazilian higher education system, 
however, it becomes evident that there are still remnants of an elitist system maintaining an inappropriate level of inequity.

Thus, since social context is still a strong conditioning factor and most students from lower-income families enrol in lower-quality, lower social status institutions, courses and modes of education, the current expansion is still partly reproducing the inequalities present in Brazil as a whole. Despite some progress, the process requires adjustments to widen opportunities and the potential for social mobility in the country.

\section{REFERENCES}

Bertolin, J., Amaral, A., \& Almeida, L. (2019). Os cursos de graduação podem compensar a falta de capital cultural e background de estudantes? Educação $e$ Pesquisa, 45, 1-18.

Bourdieu, P. (1966). L'école conservatrice: Les inégalités devant l'école et devant la culture. Revue Française de Sociologie, 7(3), 325-347.

Coleman, J. S., Campbell, E. Q., Hobson, C. J., McPartland, J., Mood, A., Weinfeld, F., \& York, R. (1981). Equality of Educational Opportunity (p. 1966). US Government Printing Office.

Corbucci, P. R. (2014). Evolução do acesso de jovens à educação superior no Brasil (No. 1950). Texto para discussão, Instituto de Pesquisa Econômica Aplicada (IPEA). Ipea.

de Souza, P. F., Ribeiro, C. A. C., \& Carvalhaes, F. (2010). Desigualdade de oportunidades no Brasil: considerações sobre classe, educação e raça. Revista Brasileira de Ciências Sociais, 25(73), 77-100.

Department of Education and Science, \& Plowden, L. (1967). Children and Their Primary Schools: Vol I: The Report: A Report of the Central Advisory Council for Education. HM Stationery Office.

Figueiredo, A. C. (2018). Limites para afiliação à vida acadêmica de estudantes de camadas populares no contexto de expansão universitária. Educação $e$ Pesquisa, 44, 1-18.

IBGE (Instituto Brasileiro de Geografia, Estatística). (2017). Coordenação de População e Indicadores Sociais. Sintese de indicadores sociais: uma análise das condições de vida da população brasileira, 2017 (No. 38). IBGE.

IBGE (Instituto Brasileiro de Geografia, Estatística). (2018). Coordenação de População e Indicadores Sociais. Sintese de indicadores sociais: uma análise das condições de vida da população brasileira, 2018 (No. 39). IBGE.

IBGE (Instituto Brasileiro de Geografia, Estatística). (2019). Desigualdades Sociais por Cor ou Raça no Brasil (Vol. 41). IBGE.

ILO (International Labour Organisation). (2018). Global Wage Report 2018/19: What Lies Behind Gender Pay Gaps. International Labour Office. 
INEP (Instituto Nacional de Estudos e Pesquisas Educacionais Anísio Teixeira). (2017). Censo da Educação. Retrieved August 7, 2019, from http://inep.gov. $\mathrm{br} /$ censo-da-educacao-superior

INEP (Instituto Nacional de Estudos e Pesquisas Educacionais Anísio Teixeira). (2019). Microdados. Retrieved March 6, 2019, from http://portal.inep.gov. $\mathrm{br} / \mathrm{web} /$ guest/microdados

IPEA (Instituto de Pesquisa Econômica Aplicada). (2017). Retrato das Desigualdades de Gênero e Raça. Retrieved August 14, 2019, from http:// www.ipea.gov.br/retrato/indicadores_educacao.html

Lemos, I. B. D. (2017). Narrativas de cotistas raciais sobre suas experiências na universidade. Revista brasileira de educação, 22(71), e227161.

Lucas, S. R. (2001). Effectively Maintained Inequality: Education Transitions, Track Mobility, and Social Background Effects. American Journal of Sociology, 106(6), 1642-1690.

Marginson, S. (2004). Australian Higher Education: National and Global Markets. In P. Teixeira, B. Jongbloed, D. Dill, \& A. Amaral (Eds.), Markets in Higher Education: Rhetoric or Reality? (pp. 207-240). Kluwer Academic Publishers.

McCowan, T. (2016). Three Dimensions of Equity of Access to Higher Education. Compare, 46(4), 645-665.

McCowan, T., \& Bertolin, J. (2020). Inequalities in Higher Education Access and Completion in Brazil. UNRISD Working Paper on Universities and Social Inequalities in the Global South. United Nations Research Institute for Social Development.

Ministério da Educação. (2019). Programa Universidade Para Todos. Retrieved August 7, 2019, from http://prouniportal.mec.gov.br/dados-eestatisticas/9-quadros-informativos

Neves, P. S., Faro, A., \& Schmitz, H. (2016). As ações afirmativas na Universidade Federal de Sergipe e o reconhecimento social: a face oculta das avaliações. Ensaio: Avaliação e Politicas Públicas em Educação, 24(90), 127-160.

OECD (Organisation for Economic Co-Operation and Development). (2018). Education at a Glance 2018. Retreived October 10, 2019, from https://doi. org/10.1787/eag-2018-en

Schwartzman, S. (2004). Equity, Quality and Relevance in Higher Education in Brazil. Anais da Academia Brasileira de Ciências, 76(1), 173-188.

Semesp (Sindicato das Entidades Mantenedoras de Estabelecimentos de Ensino Superior no Estado de São Paulo). (2019). Mapa do Ensino Superior no Brasil 2019. Retreived August 2019, from https://www.semesp.org.br/pesquisas/ mapa-do-ensino-superior-no-brasil-2019

Todos pela Educação. (2019). Anuário brasileiro da educação básica 2019. Moderna.

UNDP (United Nations Development Programme). (2016). Human Development Report 2016. Human Development for Everyone. Retreived November 19, 2019, from http://report2016.archive.s3-website-us-east-1.amazonaws.com 
WID (World Inequality Database). (2015). World View. Retrieved November 19, 2019, from https://wid.world/

World Bank. (2017). Um Ajuste Justo. Análise da eficiência e equidade do gasto público no Brasil. Retreived August 7, 2019, from http://documents.worldbank.org/curated/en/884871511196609355/pdf/121480-REVISEDPORTUGUESE-Brazil-Public-Expenditure-Review-Overview-PortugueseFinal-revised.pdf

LAWS

Lei $n^{\circ} 11.096$, de 13 de janeiro de 2005. Institui o Programa Universidade para Todos - PROUNI, regula a atuação de entidades beneficentes de assistência social no ensino superior; altera a Lei no 10.891, de 9 de julho de 2004, e dá outras providências. Brasília: Diário Oficial da União.

Lei $\mathrm{n}^{\circ} 12.711$, de 29 de agosto de 2012. Dispõe sobre o ingresso nas universidades federais e nas instituições federais de ensino técnico de nível médio e dá outras providências. Brasília: Diário Oficial da União.

Open Access This chapter is licensed under the terms of the Creative Commons Attribution 4.0 International License (http://creativecommons.org/licenses/ by $/ 4.0 /$ ), which permits use, sharing, adaptation, distribution and reproduction in any medium or format, as long as you give appropriate credit to the original author(s) and the source, provide a link to the Creative Commons licence and indicate if changes were made.

The images or other third party material in this chapter are included in the chapter's Creative Commons licence, unless indicated otherwise in a credit line to the material. If material is not included in the chapter's Creative Commons licence and your intended use is not permitted by statutory regulation or exceeds the permitted use, you will need to obtain permission directly from the copyright holder.

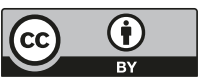

